\title{
Processes of academisation in higher music education: the case of Sweden
}

\author{
Karin Johansson ${ }^{1, *}$ and Eva Georgii-Hemming ${ }^{2}$ \\ ${ }^{1}$ Malmö Academy of Music, Lund University, Box 8203, SE-200 41 Malmö, Sweden and ${ }^{2}$ School of Music, Theatre and Art, \\ Örebro University, SE-701 82 Örebro, Sweden \\ *Corresponding author. Email: karin.johansson@mhm.lu.se
}

\begin{abstract}
Higher music education (HME) in Europe is multifaceted due to the great variety of legal frameworks, conservatory histories and practices. However, following the Bologna declaration in 1999, traditional conservatories are gradually transforming into research-based institutions, which means combining advanced performer training with artistic research. After a background on academisation in the higher education of classical, professional musicians, this article reports on a Swedish case study of meanings assigned to academisation in HME. Findings show that it is defined and justified as a quality development project, which requires adaptation and also gives opportunities for further development. Issues of agency in HME are discussed.
\end{abstract}

Keywords: Higher music education; academisation; artistic research; the music profession

\section{Introduction: music conservatoires and universities as merging institutional practices?}

A decade ago, Schippers (2007) pictured the relationship between music conservatoires and universities as not only an arranged marriage, but as a win-win coalition that provides the possibilities of

research programmes within the context of higher music education that are not at the margin, but at the core of musical life in an academic context, with pro-active links to students, staff, management, other faculties and the outside world through curriculum development, creative practice, community activities and performance. (p. 7)

In 2009, after depicting the European situation with its great diversity concerning the inclusion of research activities in institutions of higher music education (HME), Harald Jørgensen posed the question: 'Is it possible to combine research and artistic activity in a third form of activity, where research and artistic activity are related and influence each other and develop a sort of knowledge that is unavailable by the two separate activities?' (p. 94). More recently, Lundström (2013) described a complicated phase of transition for institutions of higher arts education that 'will eventually lead to a changed self-image: from that of being "institutions of education" to that of being "institutions of education and research"' (p. 136). We see these visions of merging institutional practices as manifestations of the general academisation process in European higher arts education, which forms the horizon for this paper. ${ }^{1}$ But what does the enactment of 'a close relationship between education and research’ (The Swedish Higher Education Act 1992:1434, §3) involve in 
HME practice? On the basis of a case study of Swedish HME, our overarching aim in this article is to discuss academisation, artistic research and the training of tomorrow's professional, classical musicians, departing from the question 'What meanings are assigned to academisation in HME?'

\section{Background: higher music education in times of change}

Today, conditions for the classical music profession in Western society and cultural life are changing in unknown directions. The rapid pace of societal transformation presents higher education with a number of demanding challenges, and the music area is no exception.

\section{Educating the professional musician of tomorrow}

Since the Bologna declaration in 1999, a harmonisation of the European educational system is ongoing, in order to facilitate student mobility and assessment procedures. Cross-institutional, future-oriented initiatives aiming at articulating strategies and methods for learning and creating music in HME have been taken across Europe, for example, The Reflective Conservatoire (Gaunt, 2016), Innovative Conservatoire, ICON (Duffy, 2016), Students' Ownership of Learning, SOL (Hultberg, 2010) and Teachers' Voices (Johansson, 2013). Centres such as Centre for Excellence in Music Performance Education (CEMPE) in Norway and New Audiences and Innovative Practices (NAIP) in Holland conduct practice-based investigations of the music profession. However, HME in Europe is still multifaceted due to the great variety of legal frameworks, conservatory histories and practices (Gies, 2019). Mismatches between educational structures and today's music industry are often pointed out, together with the need for change (e.g., Minors et al., 2017; Said, Myers, \& Campbell, 2017). Research on the education of orchestral/instrumental musicians is still relatively scarce (Calissendorff \& Hannesson, 2017).

The number of competencies required of today's musicians increases rapidly and new basic skills are constantly added to old basic skills (Johansson, 2012). Following the Bologna process, HME curricula increasingly emphasise students' capacity to identify their own needs for further knowledge and competence development and to develop independent strategies for artistic, technical and professional progress (AEC, 2014). Several studies focus on what musicians' professional competence should include and recommend that students be 'lifelong learners' (Smilde, 2008) in order to become, for example, 'creative entrepreneurs' (News-AEC, 2014), 'radical performers' (Leech-Wilkinson, 2016) and 'artist-researchers' (Aho, 2013).

'Reflection' is often presented as the keyword for achieving these changes. Competence in reflection and critical thinking plays an important role in HME students' preparation for insecure futures in professional musical life (Georgii-Hemming \& Johansson, 2020; Carey, Harrison, \& Dwyer, 2017) and are stated as necessary for assessing and using new knowledge throughout a professional career (Swedish Code of Statues, 2009:1037). In addition, research is increasingly forwarded as a possible instigator of renewal in HME traditions of one-to-one teaching and musical practice (Jørgensen, 2009). The Dublin Descriptors of learning outcomes have been adapted to HME needs through $\mathrm{AEC}^{2}$ initiatives and they state, for example, that the second cycle learning outcomes should relate to the dual aim of being 'the gateway to the profession' and 'the bridge to the $3^{\text {rd }}$ cycle'. In music, this is interpreted as combining advanced performer training with the preparation for artistic research (AEC, 2014, p. 65; Harrison, 2014). The ongoing transformation of traditional conservatories into research-based institutions is in this context a matter of common interest for individual students, teachers and institutions alike. While often broadly referred to as 'academisation', it is not always clear what this actually entails, and if it is seen as a top-down or bottom-up process. We will, therefore, briefly discuss the issue of how 'academisation' may be conceptualised. 


\section{The concept of academisation in the context of HME}

By tradition, HME is what Ek et al. (2013) call a 'profession-oriented' rather than a 'disciplineoriented' culture, where students are socialised into professional working life rather than into research. Ek et al. state the key features of academisation as 'greater demands to link teaching to research; requirements for teachers to hold research qualifications; and a quality assurance system that focuses on students' scientific work (rather than practical training periods)' (p. 1309). This kind of distinction between theory and practice is central to the long-standing and polarised dispute around the arts and artistic research in connection with the university, as expressed by Borgdorff: 'first you create an antithesis between (inadequate) academic research and the liberating cognitive practices of artists, and then you go on to defend the latter from unwarranted institutionalisation and normalisation' (2012, p. 5). Where theory and practice are separated, art and research are constructed as incompatible entities, scientific activities are valued higher than artistic work, and, consequently, academisation is expected to have negative effects on higher arts education. From a slightly more positive perspective, Gies (2019) outlines the long European history of this debate, which is often prejudiced in relation to the development of HME institutions (HMEIs), and pictures academisation as a dynamic process initiated from bottom-up perspectives, motivated by the following aspects (p. 46):

- The social aspect relates to an increase in social reputation,

- The formal/legal aspect relates to the award of legal standard degrees which may regulate access to certain professional activities or offices,

- The epistemological aspect relates to the recognition as a discipline whose methods of knowledge acquisition are theory- or reflection-based,

- The political aspect relates to an improvement in access to public and governmental funding, both in the area of promoting tertiary education and promoting research.

Considering these aspects, there is potentially a lot for HMEIs to gain from the academisation process. As noted by Craenen (2019) on the topic of artistic research in Dutch HME, the transformation into a research-based higher arts education does not mean the subordination to extraneous standards but gives the opportunity to develop research models that are idiomatic to the field of music. In the Nordic countries, most HMEIs had already merged with universities in the 1970s, but, as pointed out by Tønsberg (2013) who studied the academisation of jazz, pop and rock genres in Norway, this is a slow and long-term process. Dellgran and Höjer (2000), who mapped the development of the new discipline Social Work in Sweden during the late $20^{\text {th }}$ century, specify the following four criteria for measuring the progress of academisation and note that it may take years before they become visible:

- An increase in academic knowledge,

- An increase in the number of producers of such knowledge,

- The influence of academic knowledge on education,

- The influence of academic knowledge on professional life.

There are as yet no studies of the research base in contemporary Swedish HME, that is, the use and function of research and the integration between research and practice. Therefore, it is so far not possible to assess whether there is any increase and influence of academic knowledge on professional life in the field, which, according to Dellgran and Höjer are the key features of academisation.

The present study of Swedish HME should be seen in the context of the multifaceted picture of academisation in European HMEIs and the efforts made across the continent to achieve 'the integration of practice and research into the structure of the institution itself (AEC, 2014, p. 72). 


\section{A case study of contemporary Swedish HME}

This paper draws on data from the ongoing research project Discourses of Academization and the Music Profession in Higher Music Education (DAPHME) ${ }^{3}$ that investigates how processes of academisation affect HME in Sweden, Norway and Germany. In the Swedish part of the study, we conducted an interview study with teachers and institutional leaders from the four HMEIs that offer bachelor and master programmes in classical music, in order to explore the meanings assigned to academisation in Swedish HME of classical musicians. By now, Sweden has to a high degree adapted higher arts education to the Bologna system. During the last 30 years, structures for academic progression in higher arts education have been created (Biggs \& Karlsson, 2011; Lundström, 2013), with the first cycle emphasising acquisition, the second cycle application and the third-cycle generation of new knowledge. Since 2010, artistic research has been implemented in the university system with a doctoral degree and substantial governmental funding initiatives. Degrees, academic structures, positions and career paths have been established through governmental initiatives. The academisation process of Swedish HME can, therefore, when defined as the inclusion of vocational/artistic educational programmes into universities (Kyvik, 2006; Dyndahl et al., 2017), be seen as a fait accompli. In real life, the situation is of course more complex. Our report will illustrate one of the processes that form part of ongoing change in HMEIs.

\section{Methodological considerations}

In line with the framework of the DAPHME project, the starting point for this part study was the documented changing conditions for HME and the music profession in society, with the expectation that 'discourses of academisation and the music profession in higher music education, including questions of the music professions' role and mandate in society, are influenced by higher education policies as well as the Bologna and aesthetic discourses' (Georgii-Hemming et al., 2016, p. 287). Bearing in mind the multifaceted picture of European HME, these are likely to produce tensions and negotiations concerning, for example, what counts as valuable knowledge and good practice. With a discourse-theoretical perspective on knowledge, language and power (Foucault, 1971, 1994), the articulation of academisation by actors in HME can be expected to display discursive formations that regulate what is regarded as the truth, that decide who has the right to speak and that guide future actions. Methodologically, the point of interest in this study especially concerns the dialectic power relationship between, on the one hand, how discourses constitute subjects, and, on the other hand, if and how subjects may use and influence discourses. In the words of Fairclough and Wodak (1997):

Describing discourse as social practice implies a dialectical relationship between a particular discursive event and the situation(s), institution(s) and social structure(s) which frame it: The discursive event is shaped by them, but it also shapes them. That is, discourse is socially constitutive as well as socially conditioned - it constitutes situations, objects of knowledge, and the social identities of and relationships between people and groups of people. It is constitutive both in the sense that it helps to sustain and reproduce the social status quo, and in the sense that it contributes to transforming it. (p. 260)

Previous discourse-analytical studies in music education (for an overview, see Rolle, Angelo, \& Georgii-Hemming, 2017) have made this dynamic visible. One example is Nerland's study of discursive practices in one-to-one instrumental teaching (2007), where an increased awareness of their effects on the scope for musical learning is discussed as contributing to reflexive thinking and professionalisation of HME teaching. 
The eclectic approach of Critical Discourse Studies (CDS) offers tools for studying the knowledge production and power effects of discourses with a multidisciplinary approach (Wodak \& Meyer, 2016), and the present study applied a grid suggested by Jäger and Maier (2016):

- the study's background is the presumed ongoing crisis in HME, the discursive event,

- the main point of investigation is 'academisation in HME', the discourse strand,

- the Swedish academies of music together constitute the discourse plane,

- the transcribed texts from interviews make up the discourse fragments to be studied,

- the material will be analysed concerning its discourse position.

\section{Participants from Swedish music academies}

Participants from the four Swedish HMEIs that offer bachelor and master programmes in classical music performance were recruited. Institutional leaders and teachers (professors and senior lecturers) with experience of working with artistic research and bachelor's/master's degree projects ${ }^{4}$ were contacted, with the aim of interviewing four representatives from each institution. In the end, two persons dropped out due to lack of time and the study contains material from interviews with eight male and six female participants, $\mathrm{N}=14$ (see Table 1 below). The study did not include students as participants (for Swedish students' perspectives on contemporary HME, see Moberg, 2018). All participants in the study had substantial knowledge, long-term experience of and engagement with educational, curricular and institutional work.

\section{Semi-structured interviews}

Semi-structured interviews were carried out during autumn 2016 and spring 2017, equally divided by the two authors. We followed a mind map prepared in advance with relevant topics and questions. The topics addressed in the interviews were organised into four sections with corresponding

Table 1. Participants from Swedish music academies

\begin{tabular}{|c|c|c|}
\hline Participant (P)/Institution (I) & Position & Date \\
\hline $\mathrm{P} 1: 1$ & Professor/director & 10 September 2016 \\
\hline $\mathrm{P} 2: 1$ & Professor & 22 September 2016 \\
\hline P3:1 & Professor & 22 September 2016 \\
\hline $\mathrm{P} 1: 2$ & Director & 16 September 2016 \\
\hline $\mathrm{P} 2: 2$ & Senior lecturer & 10 September 2016 \\
\hline P3:2 & Professor & 8 September 2016 \\
\hline $\mathrm{P} 4: 2$ & Professor & 9 September 2016 \\
\hline $\mathrm{P} 1: 3$ & Research officer & 6 September 2016 \\
\hline $\mathrm{P} 2: 3$ & Senior lecturer & 14 February 2017 \\
\hline $\mathrm{P} 3: 3$ & Professor & 19 September 2016 \\
\hline $\mathrm{P} 1: 4$ & Director & 27 September 2016 \\
\hline P2:4 & Head of programme & 29 September 2016 \\
\hline P3:4 & Professor & 27 September 2016 \\
\hline P4:4 & Senior lecturer & 26 September 2016 \\
\hline
\end{tabular}


questions (see Appendix): (i) notions of skills and competencies necessary for today's students, (ii) experience of and thoughts on artistic research, (iii) comments on academisation processes and (iv) views on the music profession. In the individual interviews, the sections overlapped and were all related to institutional discussions and developments.

Each interview lasted 60-90 min and was recorded in audio format. The data were then transcribed and imported into the data analysis platform NVivo, in order to facilitate sharing between the investigators. In the result presentation below, quotations have been edited for readability.

\section{Analysis}

A structural analysis of the texts with 'academisation' as the discourse strand resulted in categorising four subtopics that emerged from the data. Following the coding of selected discourse fragments, a detailed analysis of vocabulary and rhetoric as related to the context of the ongoing transformation of HME as the discursive event was carried out. For example, the implementation of artistic research in the educational system is an important part of the discipline-specific knowledge development the academisation process - in HME. This motivated an in-depth analysis of how research and reflection are implicitly and explicitly legitimised and justified. The coding procedure, therefore, focused on qualities and features attributed to reflection and research. Overall, the methodological procedure can be described as an abductive, circular movement between data and theory, with a focus on the power and use of discourse in the specific sociocultural context of HME.

\section{Findings: academisation as a quality development project}

An overarching answer to this article's main question - 'What meanings are assigned to academisation in HME?' - is that academisation in Swedish HME is defined and justified as a quality development project, around which the data demonstrate a relative agreement. The definition of academisation as a dynamic progression towards higher educational standards positions subjects as co-producers of the process and provides scope for verbalising complex issues concerning institutional agency, educational content and relationships to the profession:

The interesting question is if we educate students for an already defined music industry or if we are also agents in the creation of the music industry. Students need to become specialists but they also need breadth and depth, and we cannot lose the one in chase of the other. (P2:4)

However, the picture is more complex than suggested by the quote above.

The discourse Academisation as a quality development project has formed during decades of work with structural change. Discourses determine what is perceived as reality at the same time as they are continuously produced by active subjects in specific contexts, and this dynamic is visible throughout our data.

As outlined at the beginning of the article, academisation may be conceptualised on a sliding scale from top-down implementation of new educational structures to bottom-up endeavours that increase influence and status on the part of the arts. Correspondingly, subject positionings are possible between victim and agent, at either end of the scale.

We will now present the meanings assigned to academisation as a quality development project categorised as four subtopics that emphasise different positionings on such a scale: (i) adaptation to top-down procedures, (ii) transformation of programmes and mindsets, (iii) building a research-based education and (iv) developing HME for the future. The accompanying quotes encompass and illustrate this dynamic. 


\section{Adaptation to top-down procedures}

The implementation of the Bologna process is described as originally resulting from top-down procedures implemented in HME, and as handled through a combination of adaptation, resistance and co-creation, but never through opposition to the project as such. This exemplifies how the scope for critical views has discursive limits. Typically, criticism is balanced by positive statements that emphasise the necessity of adaptation, for example:

First, academisation is about adaptation; we can also influence the situation, but it's sometimes an uncomfortable process. It's about adaptation to the university system. Second, it's about academic competence, which often means reading and writing. [...] We adapt to systems of evaluation, curricula and examination, but there has to be some kind of artistic freedom. A certain amount of academic competence is good but sometimes it's as if we constantly have to guard and defend the artistic freedom. (P1:4)

Adapting to the university system is pictured as a necessary tool for students, who are bound to encounter the contemporary crisis for the music profession:

Culture and the arts are not a given part of social life anymore, [ . . ] everyone has to motivate their own existence and we have to provide students with tools to fight for their own. It's a cruel world where they are alone, and we have to help them. (P2:2)

Necessary changes risk resulting in more or less uncontrollable bureaucratisation:

Structuring a programme as courses can really promote quality. The other side of the coin is a type of bureaucratisation that turns educational programmes into production units, and we lose the possibility to do things that are not established in curricula [...] This goes back to the well-meaning ambition to make everything examinable and to safeguard legal certainty for the students, but in practice it has meant many small steps in the completely wrong direction. What was perceived as a legal right in fact meant playing into the hands of New Public Management. Its good side - transparency - is hard to argue against, but it may lead in the wrong direction. (P4:2)

Academisation is here described as a process which is necessary and requires adaptation. Without the possibility to influence, it may have negative consequences for quality development.

\section{Transformation of programmes and mindsets}

The Bologna process necessitates a change in both students' and teachers' mindsets, along with fundamental transformations of teaching and educational programmes:

This is a university education, and the time of 'only' playing an instrument is over. If that's what you want, you might just as well study for a private teacher. The dominance of the conservatory-type of teaching where the door closes on teachers and students and no one knows what happens in there, is also over. Of course we need one-to-one teaching but proficiency training has to be complemented by other forms of tuition. (P1:1)

The transition from master-apprentice to student-centred teaching involves relating to HME content in new and challenging ways: 
When new music styles enter HMEIs they soon go out of fashion, but we need a constant integration of new genres and a broader recruitment of students. This is an enormous challenge since we're a higher education in a university and need to be able to examine reflection and critical thinking. But it's also a pedagogical opportunity where we as an institution can imitate and import so-called informal ways of teaching and learning from musical practices outside the university; look at hip-hop, for example. (P3:2)

When traditional ways of teaching and examining students in HME are giving way to programmes structured as courses, quality development in line with the Bologna process is pictured as an urgent issue that involves teachers as well as programme directors:

We spend far too much time on communicating to students what they already know. They know how to read a syllabus and how to find resources. But the subtle parts, like how to relate to degree objectives on a national level, we don't highlight at all. We have far too little teacher interaction and would need to work much more on curriculum and examination issues. (P2:3)

The university system and the music profession differ when it comes to quality assessment and becoming part of the evaluation society is seen as necessary. Playing well is not enough:

Programmes are often old-fashioned, pre-Bologna, and build on just playing more and more. There has to be a progression between $1^{\text {st }}$ and $2^{\text {nd }}$ levels; at $2^{\text {nd }}$ level students have to have a greater understanding of their own artistic practice. (P4:4)

However, HME already has traditional systems for evaluating quality:

Although our institution is relatively unbureaucratic, we actually meet the quality criteria, and certain of our attributes assure quality. For example, all our part-time instrumental teachers who are also orchestral musicians know exactly what students need in their profession and are able to transfer this knowledge to them. They know how to win an audition. They know about the hierarchies in a symphony orchestra. They know about performance practice. It's a mechanism for quality assurance, and it's the same in all academies. (P3:4)

New, standardised measurement formats may be counterproductive to quality development:

On an institutional level, national evaluations are forceful instruments for measuring what we deliver. In our case, it pushes us towards uniform, more rigid, formats for the degree project. They are supposed to safeguard speedy delivery, but this focus is sometimes counter-productive to quality development, both in the students and in the institution. (P2:2)

On the other hand, important questions such as how artworks relate to peer-review publications may be articulated:

By now, I think many have realized that there is something in it for them, and the important discussion concerns what a publication is in our field; it cannot be just a concert. The artwork has to be contextualized, that is, put into some kind of perspective or field of tension before it becomes research. It's not that it should sound different, but a perspective with theories, comparisons or concepts is needed in order to create new knowledge. And then it has to be articulated and communicated. (P3:2)

Academisation is here portrayed as a challenge that can be met. The pros and cons of implementing curricular change in the Bologna system are clearly spelled out. Arguments that motivate the 
social relevance of artistic activity and explain the need for new structures are put forward, as well as ideas for achieving change.

\section{Building a research-based artistic practice}

The introduction of research components in the first and second cycles aims at preparing and qualifying students for the third-cycle research, that is, building a research-based higher education. In Sweden, the artistic PhD degree has established artistic research as the main way of enquiry for developing new knowledge in the field of music. Strong views on how the discipline should be shaped are articulated, for example, that artistic practice in itself cannot be seen as research:

All research is a systematic inquiry with the aim of increasing general knowledge. The difference between artistic and scientific research is a question of methods more than anything else. I see artistic research as a hybrid field, where the artistic work is one part. The artistic work can never be research on its own. A very basic demand on research is that it's intended as such. (P2:3)

A debate around the central aspects of artistic research has been ongoing in Sweden for decades. It is a young discipline, and many agents take part in disciplinary development:

Many artistic research projects have been done in a kind of opposition towards traditional research, and that blocks the possibilities for interdisciplinary projects. Of course, it's good that $\mathrm{PhD}$ candidates object to or disagree with various issues, but you don't see many physicists who disagree with the scientific method. There are already some $\mathrm{PhD}$ candidates who object to artistic methods, and that's healthy, since the problem of the Swedish artistic research development is that the definition of research has been left entirely to them. (P2:3)

The difficulties for performance programmes in increasing the contact between research, teaching and performance through the first, second and third cycles are spelled out:

In general, the relationship between research and graduate education is not good. Not between research and teachers either. All areas would benefit from a closer contact, but everyone is busy with their own projects. For example, one of our $\mathrm{PhD}$ candidates who is also an internationally renowned pianist, held a seminar last week. The piano department should have attended but nobody turned up. (P1:4)

A key principle of Swedish artistic research since the start has been its legitimacy in professional music life as well as in academia. It is mentioned as crucial that 'artistic research is done by prominent musicians with a credibility in their field, otherwise, the value of the research will be undermined' (P3:1). The competition for positions in the field is severe and the risk of creating an elite with artistic PhDs, which simultaneously might cause a de-professionalisation in HME, is pictured as a specific complication:

There is a risk of creating first-class and second-class teams, and we always need to be able to employ high-ranking musicians even if they do not have a PhD. There is also a risk of deprofessionalization instead of a professionalization of our staff, and we might lose prestige and competence in the field of HME instead of gaining. (P1:2)

Academisation is here described as a process that requires action and initiative, where the new discipline of artistic research has to be formed and developed by the actors involved. 


\section{Developing HME for the future}

The research-oriented degree project in the first and second cycles of HME has gradually emerged as a discipline-specific instrument for individual as well as institutional development. It was implemented in Swedish music performance programmes after 2007 and the most common model is a construction that contains a performance part and an independent reflective project presented in writing, multimedia or through the lecture recital format.

We have directives for the reflective part, so that students learn the craft, and understand that this aims at both personal development and development of the profession. The master degree project is an independent artistic project but should also demonstrate an awareness of the context; as a musician, you are not acting in an isolated room. This means not only written sources but all kinds of influences and references. By now, we see a positive connection between bachelor and master levels on the parts of the students. (P1:1)

The degree project was initially much debated. On the one hand, it was rejected as not relevant, even destructive, to musicians' development; on the other hand, it was seen as crucial for adding skills to the traditional professional profile. Today, its existence is seldom contested:

The resistance from instrumental teachers has decreased, even disappeared, probably because they see that it is beneficial for the students. They have understood that we have to do this and that other academies do it too. We now see a progression in the quality of these projects from $1^{\text {st }}$ to $2^{\text {nd }}$ cycle, that's inspiring. (P2:4)

The awareness of reflection as inherent to music-making is emphasised as the foundation for degree projects:

We have always used the format of a documented examination concert, and when we had to adapt to Bologna, we added a part that makes the surrounding reflection visible. It's very important to emphasize that reflection is always there in the process of making music. We have developed the format over time, and the lecture recital aims both at this kind of format development and at giving those who don't want to or can't use text an opportunity. (P3:4)

It is repeatedly stressed that the degree project is based on discipline-specific knowledge:

It's important that the project is founded on artistic research and related methods. Otherwise it turns into a separate business, where students think they have to write a musicological essay about a piece. Their main area, where they have real knowledge is their instrument, or composition. For example, if they write about stage fright and use music psychology, that's a problem because they don't have any knowledge in that area. They have to use their competence in their own field. (P4:4)

The establishment of artistic research as a discipline is pictured as a decisive factor:

Look at the latest decade, artistic research has contributed so much to degree projects by demonstrating how to integrate reflective and artistic activities, and how to document and present research in multimodal formats. (P3:3)

Artistic research has been fantastic in deconstructing old dichotomies, and we need that way of thinking in the degree projects as well. [...] Ongoing and previous research points to what questions to focus on, how to work with them, what questions are relevant to 
musicians ... We have to follow that development, and not get stuck with ready-made forms and stereotypes. (P2:2)

By now, the projects are pictured as having a possible impact on future HME:

The degree projects are actually characterized by idealism. The students are driven by a love of music, certain expressions, and there is not much speculation [...] The degree projects give hope for the future of HME. Many are both conventional and experimental, they cross borders and investigate new things. (P3:4)

Academisation here comes across as an opportunity for HME, where all participants contribute to and influence its future development. The degree project is described as a forum for exploring valid present-day knowledge for professional musicians, and for documenting competence and personal development in the portfolio format. As a tool for assessment as well as for individual learning (Habib \& Wittek, 2007), it is both a mirror of and an instrument for quality development.

\section{Discussion: academisation and agency}

As shown above, Academisation as a quality development project encompasses subtopics that display a variety of positionings when it comes to agency, depending on what is focused on the assignment of meaning. Academisation necessitates adaptation and transformation. Academisation inspires the building of new educational structures and its process is shaped by actors in HME. That is, the discourse determines what is perceived as 'reality' but is also used for creating and changing this 'reality'. Its functions in Swedish HME may be described as to:

- provide a vocabulary through which actors such as the interviewed teachers and leaders evaluate, interpret and handle their situations,

- enable the expression of differing, even opposing, views and simultaneously hold discursive limits for what is sayable and makeable,

- balance frustration through the verbalisation of tensions,

- legitimise and justify current initiatives such as the implementation of curricular change; if and when they are defined as instruments for quality development,

- support the creation of conceptual frameworks for teaching and supervising,

- facilitate the development and materialisation of educational outcomes such as the bachelor's/master's degree project.

What is not mentioned in the list above is the function of exclusion; a discourse determines who may speak and what is possible to say. This study, which was made at a specific moment in time with a specific sample of teachers and institutional leaders, demonstrated an absence of explicitly voiced severe tensions. The data is characterised by what might be called a negotiated consensus, with statements such as 'The resistance from instrumental teachers has decreased, even disappeared ...' Rather than an illustration of how everyone is now happy, we interpret this as a representation of discursive limits; today it is no longer politically correct to openly voice complaints about the ongoing transformation. However, we also interpret 'negotiated consensus' as a sign of maturity in the overall organisation of Swedish HME; contradictions and tensions may be articulated, moderated and processed through this discourse, which consequently provides tools for thinking about and creating future initiatives. This means that the discourse per se can be used as an instrument for promoting further change and quality development. What might be called a discourse awareness may offer to HMEIs and individual actors in HME alike the possibility to reflect upon power structures and their own agency. As pointed out by Jäger and Maier 
(2016), 'Foucauldian discourse theory contests the existence of an autonomous subject, but that does not mean that it is against the subject. The active individual is fully involved when it comes to realizing power relations in practice' (p. XX 2.4).

Interestingly, while the discourse highlights the need to adapt to ongoing sociocultural change, views or visions on the fundamental reasons for educating professional musicians today are lacking. That is, while the need for individual artists to become lifelong learners who critically reflect on their professional roles on an individual level is emphasised, critical reflection on the part of the HMEIs themselves is not equally visible. Here, a comparison between European countries would be valuable. It seems that in the Swedish context, a general discussion on the social mandate of HMEIs, the impact of the marketisation of art and the role of potential artist-researchers in future HME remains to be developed.

The general discussion about research in higher arts education during the last decade has elucidated fundamental disagreements when it comes to the aims, focus and content of artistic research as one discipline. The clearest split in this matter concerns the question of whether art in itself equals research or if artistic research as a new discipline requires new methods and produces new kinds of knowledge (Borgdorff, 2012; Lindberg Sand \& Sonesson, 2015). In Sweden, this debate has been conducted across the art forms, and in the area of music the direction has been fairly unified from the start: reflection is an inherent capacity of every kind of musicianship but also an ability that has to be trained in other ways. Academisation as a quality development project strongly emphasises this view, for example, in phrases such as 'artistic work can never be research on its own'. Artistic research in music consequently includes but cannot be the same as the artwork itself and corresponds to what Jørgensen (2009) calls 'a third activity', in the respect that it opens up for and claims a new area of knowledge where actors position themselves as agents.

\section{Concluding remarks}

This study reports on one context of many in the ongoing transformation of HME in Europe. Its results may be a ground for comparisons and dialogues about ways ahead on a transnational level and provide input concerning the implementation of connections between research and artistic practice.

Contemporary higher education of professional, classical musicians is a context of exciting potential as well as of severe challenges. The power to influence its future development rests with actors at all levels in the system, as a possibility and a responsibility. Positioning oneself - be it as an institution or an individual - as victim or agent in relation to academisation is never a private affair. It means playing a part in the game of knowledge, language and power, where every standpoint supports an agenda and where rules produce 'truths', but where agency is also an option: 'In a given game of truth, it is always possible to discover something different and to more or less modify this or that rule, and sometimes even the entire game of truth' (Foucault, 1994, p. 207).

\section{Notes}

1 While a focus on the Doctor of Musical Arts (DMA) as developed mainly in the USA is beyond the scope of this article, it would be an important further issue. For a discussion of the DMA as compared to European third-cycle programmes, see the AEC publication Perspectives on 2nd Cycle Programmes in Higher Music Education (2014, p. 20).

2 Association Européenne des Conservatoires, Académies de Musique et Musikhochschulen.

3 DAPHME is conducted by a team of six senior researchers in Sweden, Norway and Germany. The project is funded by the Swedish Foundation for Humanities and Social Sciences (Riksbankens Jubileumsfond).

4 The term 'degree project' is used in this article for describing the research-oriented equivalent to bachelor and master theses introduced in the first and second cycles of HME. In Swedish HME, it was introduced around 2007 and the most common model contains a performance part and an independent reflective project presented in writing or a multimedia format. 


\section{References}

AEC (Association Européenne de Conservatoires, Academies de Musique et Musikhochschulen) (2014). Perspectives on 2nd Cycle Programmes in Higher Music Education. Brussels: Lifelong Learning Programme.

Aho, M. (2013). Artistic research in music versus musicological musicianship. Swedish Journal of Music Research, 95, 65-78.

Biggs, M. \& Karlsson, H. (Eds) (2011). The Routledge Companion to Research in the Arts. New York: Routledge.

Borgdorff, H. (2012). The Conflict of the Faculties: Perspectives on Artistic Research and Academia. Leiden: Leiden University Press.

Calissendorff, M. \& Hannesson, H. F. (2017). Educating orchestral musicians. British Journal of Music Education, 32(2), 217-223.

Carey, G., Harrison, S. \& Dwyer, R. (2017). Encouraging reflective practice in conservatoire students: a pathway to autonomous learning? Music Education Research, 19(1), 99-110.

Craenen, P. (2019). Artistic research as an integrative force in the master's curriculum at the conservatory. Forum + , http:// forum-online.be/nummers/herfst-2019/artistic-research-integrative-force

Dellgran, P. \& Höjer, S. (2000). Kunskapsbildning, akademisering och professionalisering i socialt arbete [Knowledge, academization and professionalization in social work]. Gothenburg: Gothenburg University: Department of Social Work.

Duffy, C. (2016). ICON: Radical professional development in the conservatoire. Arts and Humanities in Higher Education, 15(3-4), 376-385.

Dyndahl, P., Karlsen, S., Graabræk Nielsen, S. \& Skårberg, O. (2017). The academisation of popular music in higher music education: the case of Norway. Music Education Research, 19(4), 438-454.

Ek, A.-C., Ideland, M., Jönsson, S. \& Malmberg, C. (2013). The tension between marketisation and academisation in higher education. Studies in Higher Education, 38(9), 1305-1318.

Fairclough, M. \& Wodak, R. (1997). Critical discourse analysis. In van Dijk, T. A. (Ed.), Discourse as Social Interaction (pp. 258-284). London: Sage.

Foucault, M. (1971). Orders of discourse. Social Science Information, 10(2), 7-30. doi: 10.1177/053901847101000201

Foucault, M. (1994). Ethics. Subjectivity and Truth: Essential Works of Michel Foucault (Vol. 1). New York: The New Press.

Gaunt, H. (2016). Introduction to special issue on the reflective conservatoire. Arts \& Humanities in Higher Education, 15(3-4), 269-275.

Georgii-Hemming, E., et al. (2016). Artist or researcher? Tradition or innovation? Challenges for performing musician and arts education in Europe. In L. Väkevä, E. Georgii-Hemming, S-E. Holgersen \& Ø. Varkøy (eds.), Nordic Research in Music Education Yearbook (Vol. 17, pp. 279-292). Oslo: NMH-publikasjoner.

Georgii-Hemming, E. \& Johansson, K. (2020). Reflection in higher music education: what, why, wherefore? Music Education Research, 22(3), 245-256. DOI: 10.1080/14613808.2020.1766006

Gies, S. (2019). How music performance education became academic. On the history of Higher Music Education in Europe. In S. Gies \& J. H. Sætre (eds)., Becoming Musicians. Student Involvement and Teacher Collaboration in Higher Music Education (pp. 31-51). Oslo: The Norwegian Academy of Music.

Habib, L. \& Wittek, L. (2007). The portfolio as artifact and actor. Mind, Culture and Activity, 14(4), $266-282$.

Harrison, S. D. (2014). Research and Research Education in Music Performance and Pedagogy. Dordrecht: Springer Netherlands.

Hultberg, C. (2010). Students' ownership of learning (SOL). Stockholm: Myndigheten för nätverk och samarbete inom högre utbildning [The Swedish Agency for Networks and Cooperation in Higher Education].

Johansson, K. (2012). Experts, entrepreneurs and competence nomads: The skills paradox in higher music education. Music Education Research, 14(1), 47-64.

Johansson, K. (2013). Walking together with music. Teachers' voices on the joys and challenges of Higher Music Education. Malmö: Malmö Academy of Music.

Jäger, S. \& Maier, F. (2016). Analysing discourse and dispositives: A Foucauldian approach to theory and methodology. In R. Wodak \& M. Meyer (eds)., Methods of Critical Discourse Studies (pp. 109-136). London: Sage.

Jørgensen, H. (2009). Research into Higher Music Education. An Overview from a Quality Improvement Perspective. Oslo: Novus Press.

Kyvik, S. (2006). Endringsprocesser i høyskolesektoren $i$ Vest-Europa [Processes of Transformation in the Western European Higher Education Sector]. Oslo: NIFU STEP.

Leech-Wilkinson, D. (2016). Classical music as enforced Utopia. Arts \& Humanities in Higher Education, 15(3-4), 325-336.

Lindberg Sand, Å. \& Sonesson, A. (2015). Contextual and conceptual ambiguities in the supervision of artistic research. In H. Frisk, K. Johansson \& A. Lindberg-Sand (eds)., Acts of Creation. Thoughts on Artistic Research Supervision. Höör: Brutus Östlings bokförlag Symposion.

Lundström, H. (2013). Artistic research and the transformation of art educational institutions. Swedish Journal of Music Research, 95, 131-137.

Minors, J., Burnard, P., Wiffen, C., Shihabi, Z. \& van der Walt, J. S. (2017). Mapping trends and framing issues in higher music education: Changing minds/changing practices. London Review of Education 15(3), 457-473. 
Moberg, N. (2018). Academic musicians: How music performance students in Sweden re-/negotiate notions of knowledge and competence. Nordic Research in Music Education Yearbook, 19, 73-54. Oslo: NMH-publikasjoner.

Nerland, M. (2007). One-to-one teaching as cultural practice. Two case studies from an academy of music. Music Education Research, 9(3), 399-416.

News-AEC. (2014). The Musician as a Creative Entrepreneur. Retrieved from https://www.aec-music.eu/events/polifoniafinal-conference-the-musician-as-creative-entrepreneur

Rolle, C., Angelo, E. \& Georgii-Hemming, E. (2017). Mapping the methodological field of discourse analysis in music education research: A review study, part I. In A. J. Cvetko \& C. Rolle (eds)., Musikpädagogik und Kulturwissenschaft [Music Education and Cultural Studies] (pp. x-x). Münster: Waxmann Verlag.

Said E. W., Myers D. E. \& Campbell, P. S. (2017). Redefining Music Studies in an Age of Change. Creativity, Diversity, and Integration. New York and London: Routledge.

Schippers, H. (2007). The marriage of art and academia - challenges and opportunities for music research in practice-based environments. Dutch Journal for Music Theory, 12(1), 34-40.

Smilde, R. (2008). Lifelong learners in music; research into musicians' biographical learning. International Journal of Community Music, 1(2), 243-252.

Swedish Code of Statues (SFS) No: 2009:1037. The Higher Education Ordinance. Ministry of Education and Research, Sweden. Issued: 4 February 1993.

Tønsberg, K. (2013). Akademiseringen av jazz, pop og rock - en dannelsereise [The Academisation of Jazz, Pop and Rock - an Educational Journey]. Trondheim: Akademika Forlag.

Wodak, R. \& Meyer, M. (eds.) (2016). Methods of Critical Discourse Studies. London: Sage.

\section{Appendix: Interview questions, structured in four areas}

1. Notions of skills and competencies necessary for today's students What skills and competencies are necessary for today's professional musicians?

What differences can be identified as compared to the situation 10-15 years ago?

2. Experience of and thoughts on artistic research What is the role and function of artistic research in the education of professional musicians?

What is your view on the relationship between research and practice in higher music education?

3. Comments on academisation processes

What is your view of academisation in higher music education?

4. Views on the music profession

What role and function do you see for professional classical musicians today?

How do you prepare music students for working life?

Cite this article: Johansson K. and Georgii-Hemming E (2021). Processes of academisation in higher music education: the case of Sweden. British Journal of Music Education 38, 173-186. https://doi.org/10.1017/S0265051720000339 